\title{
The Impact of Real Exchange Rate Volatility on Exports to U.S.: A Comparison between Developed and Export-oriented Less Developed Countries
}

\author{
Jianbin Situ ${ }^{1}$ \\ ${ }^{1}$ School of Economics and Management, Zhuhai City Polytechnic, China \\ Correspondence: Jianbin Situ, School of Economics and Management, Zhuhai City Polytechnic, West Lake City \\ Jin Erlu, Jinwan District, Zhuhai, Guangdong, China. E-mail: kbszeto@126.com
}

Received: December 30, 2014

Accepted: February 13, $2015 \quad$ Online Published: April 20, 2015

doi:10.5539/ijbm.v10n5p214

URL: http://dx.doi.org/10.5539/ijbm.v10n5p214

\begin{abstract}
Real exchange rate volatility on exports is an important topic in international trade and finance. However, litter studies analyzed whether the effect of real exchange rate volatility on export will change overtime. This paper categorizes the countries into two groups, namely the developed countries and export oriented less developed countries (LDCs), and divided the whole time period into two sub-periods, i.e. 1994 to 2007 and 2008 to 2014, in order to study whether the effects of volatility on exports to U.S. were different for countries with different economic characteristics and whether it changed over time. At the end, this paper discovered that the real exchange rate volatility had a bigger impact on developed countries than export-oriented LDCs, and the impact had increased in the later period. The weaker flexibility in distribution network of firms also explained why export-oriented LDCs' exports are less sensitive to real exchange rate volatility.
\end{abstract}

Keywords: real exchange rate, volatility, misalignment, panel data

\section{Introduction}

\subsection{The Effect of Volatility on Exports}

Whether real exchange rate volatility affects exports is an essential topic in international finance and international trade. Theoretically, if international traders are risk averse, and exchange rate volatility is costly, they should reduce the value of international trade flow in order to lower the risk exposure. This negative relationship between the real or nominal exchange rate volatility and exports is support by literature (e.g., Arize, 1995; Holly, 1995; Oskooee \& Hegerty, 2009; Nishimura \& Hirayama, 2013).

However, real exchange rate volatility has different impact on exports of countries with different economic characteristics. Majority of literatures discovered that real exchange rate volatility has a negative relationship with exports, while this negative relationship is stronger for developing countries than for developed countries (Sauer \& Bohara, 2001; Grier \& Smallwood, 2007). In addition, Lastrapes and Koray showed (1989) that the impact of real exchange rate volatility on international trade is bigger under floating exchange rate than fixed exchange rate.

As mentioned above, the inverse effect of real exchange rate volatility is larger for developing countries. Nevertheless, Sauer and Bohara (2001) found out that this relationship did not exist in Asian countries, but only in those of Latin America and Africa. Moreover, although there were hedge mechanism in developed countries to minimize the currency risks, the real exchange rate risk still cannot be fully eliminated because of the price level also matter. Also, hedge currency risk also involves cost. Arize (1997) showed that even highly developed countries, i.e. all of the G-7, nominal exchange rate volatility could still lower the real exports.

In this paper, the relationship between real exchange rate volatility and exports values is studied. This study also analyzes this impact on two different groups, namely the developed countries and export-oriented LDCs.

\section{Literature Reviews and Method}

\subsection{The Measurement of Volatility}

Some empirical studies, such as Koray and Lastrapes (1989) and Chowdhury (1993), use the moving standard 
deviation of the growth rate of real exchange rate as a proxy of real exchange rate volatility. Specifically,

$$
\mathrm{V}_{\mathrm{t}}=\sqrt{\frac{1}{\mathrm{~m}} \cdot \sum_{\mathrm{i}=1}^{\mathrm{m}}\left[\ln \left(\operatorname{RER}_{\mathrm{t}+\mathrm{i}-1}\right)-\ln \left(\operatorname{RER}_{\mathrm{t}+\mathrm{i}-2}\right)\right]^{2}}
$$

Where $\mathrm{m}$ is the order of moving average of the standard deviation, RER is the real exchange rate, $t$ denotes time $t$. This kind of measurements at least has two drawbacks. First, the standard deviation is an ex-post concept. The international trader can know the standard deviation only after the actualization of the RER, i.e. they cannot know the moving standard deviation of time $t$ at time $t-1$, but can only know at time $t+m$. Therefore, this ex-post measurement is not decision relevant. Second, the moving standard deviation does not take the information available for traders at time $t$ in to account, thus it ignores the fact that traders will estimate the expected volatility by using information at time $t$.

Therefore, the later empirical studies used $\mathrm{ARCH}$ or GARCH to estimate the volatility of real exchange rate (e.g. Doroodian, 1999; Fang, Lai \& Miller, 2009; Serven, 2003). The ARCH or GARCH model assumes the expected RER follows an AR process, and the residual variance of the RER also follows a AR process, i.e. conditional heteroscedasticity. As mentioned by Pozo (1992), the first advantage of using ARCH or GARCH is that it can capture the effect of volatility clustering phenomenon. In financial time series, usually high volatility period is followed by high volatility period, while tranquil period is followed by tranquil period. Therefore, the ARCH or GARCH model can better reflect the behavior of RER volatility. Second, Lee (1999) pointed out that GARCH can represent the "perceived size of the unpredictable variation". Therefore, it is an ex-ante measurement and decision relevant. Lee (1999) also argued that GARCH model excluded the predictable part of exchange rate variation, i.e. the part explained by AR model, and this predictable variation is not relevant to risk-averse traders. Therefore, in the following part of this paper, GARCH is used as a measurement of real exchange rate volatility.

\subsection{The Model Specification}

This study refers to the regression model from Li et al. (2006) with some modifications,

$$
\ln \mathrm{X}_{i, t}=\alpha_{i}+\beta \ln Y_{t}+\theta \ln R E \mathrm{R}_{i, t}+\omega \sqrt{V_{i, t}}+\phi M \text { is }_{i, t}+\varepsilon_{i, t}
$$

$\mathrm{X}_{\mathrm{i}, \mathrm{t}}$ : Real exports value in currency $\mathrm{i}$ from country i to U.S. at time t, i.e. exports value in currency i divided by CPI in country $i$.

$\mathrm{Y}_{\mathrm{t}}$ : Real personal consumption expenditure (PCE) in USD at time t, i.e. PCE divided by CPI of U.S. (2010= 100).

$\mathrm{RER}_{\mathrm{i}, \mathrm{t}}$ : Real exchange rate of U.S. to countries i, i.e. $\left(\frac{\mathrm{e}_{\frac{\text { uncrency }}{\text { Us }}}}{\mathrm{CPI}_{\mathrm{us}}}\right)$. The period average of price level of 2010 represents 100 in CPI.

$\mathrm{V}_{\mathrm{i}, \mathrm{t}}$ : Real exchange rate volatility estimated by using $\operatorname{GARCH}(1,1)$.

$\mathrm{Mis}_{\mathrm{i}, \mathrm{t}}$ : Real exchange rate misalignment, the cyclical term in the Hodrick- Prescott filter.

The GARCH $(1,1)$ model is,

$$
\begin{aligned}
& \operatorname{lnRER}_{\mathrm{t}+1}=\mathrm{A}+\rho \operatorname{lnRER} \mathrm{n}_{\mathrm{t}}+\mathrm{e}_{\mathrm{t}} \quad \mathrm{e}_{\mathrm{t}} \sim\left(0, \sigma_{\mathrm{t}}^{2}\right) \\
& \sigma_{\mathrm{t}}^{2}=\mathrm{a}+\lambda_{1} \mathrm{e}_{\mathrm{t}-1}^{2}+\lambda_{2} \hat{\sigma}_{\mathrm{t}-1}^{2}+v_{\mathrm{t}}
\end{aligned}
$$

As monthly GDP data are not reported in U.S., this study employed the personal consumption expenditure (PCE) data as alternative. The variables Y and RER are simple. If the U.S. residents' purchases increase, or the USD appreciates, exports from country i should increase. V is the estimated $\sigma^{2}$ in the GARCH model. Since V is a second moment measurement and it is the expected residual variance, this paper take the square root in order to make it more similar to expected standard deviation of residuals and give a more easily understandable meaning.

This model in this paper differs from that of Li et al. (2006) in the sense that I use the FEM (Fixed Effect Panel Model), i.e. each cross section has its own intercept Another difference is that in the GARCH $(1,1)$ model, I take natural logarithm to the real exchange rate in order to capture the non-linear effect.

Finally, the variable of Mis (the real exchange rate misalignment) in this paper is the cyclical term in the H-P filter (Hodrick-Prescott filter). The long run equilibrium RER as suggested by Li et al. (2006) is the RER when PPP holds. However, this value is unobservable. They thus used the long run average of relative exchange rate 
and prices level for inferring the long run equilibrium RER. As pointed out by the above authors, this deviation suffers from multi-collinearity with the variable RER since the long run equilibrium RER seldom changes. Therefore, this study transfers this deviation into absolute form. However, when the absolute form is used, the model can no longer distinguish whether the deviation is upside or downside. Therefore, the effects of these two different phenomena cannot be estimated.

According to Hedrick and Prescott (1997), the H-P filter decomposes a time series into a long run path component and cyclical component,

$$
\mathrm{y}_{\mathrm{t}}=\tau_{\mathrm{t}}+\mathrm{c}_{\mathrm{t}}
$$

Where $y$ is the time series, is the long run path component and $\mathrm{c}$ is the cyclical component. In order to smooth the long run path component, the following minimization condition is imposed,

$$
\min \sum_{t=1}^{T}\left(y_{t}-\tau_{t}\right)^{2}+\lambda \sum_{t=2}^{T-1}\left[\left(\tau_{t+1}-\tau_{t}\right)-\left(\tau_{t}-\tau_{t-1}\right)\right]^{2}
$$

The first square term is to minimize the gap between the trend component and the actual observation; the second square term is to minimize the second difference of the trend component. In other words, the H-P filter smoothen the series and minimize the deviation from the actual observation. According to Hodrick and Prescott (1997), $\lambda$ for monthly data should be 14400 . The first advantage of H-P filter in estimate the RER misalignment is that it focuses on the deviation of RER from the long run path rather than from the unobservable equilibrium exchange rate, which is hard to measure and defined. The second advantage is that H-P filter allows the long run path to move. Therefore, the multi-collinearity problem can be reduced. In our study, y is the natural logarithm of RER, c, i.e the cyclical component, represents the misalignment.

\subsection{Panel Data Sets}

In this paper, data are divided into two panels. One is developed countries, another is export-oriented LDCs. Developed countries include Canada, Japan, United Kingdom, Switzerland and Sweden, and export-oriented LDCs include Mexico, South Korea, Malaysia, Thailand and India. The selection criterion is the top five countries within their group according to their accumulative exports value to U.S. in USD since 2000. In the selection, Euro area countries are dropped in order to avoid losing exchange rate data. Also, petroleum exporting countries and recent WTO members are excluded. Finally, Brazil also dropped because it adopted the import substitution strategy in the late 20th century (Note 1). Time period is also divided into two sub-periods to see whether the effect of volatility change after the 2008 Financial Crisis. The first period ranges from January 1994 to December 2007, while the second period ranges from January 2008 to October 2014. Observation frequency is monthly.

Data of exports value of country i to U.S. in USD are from the database of the U.S. Census Bureau. Data of U.S. personal consumption expenditure derived from Bureau of Economic Analysis. Exchange rates come from Federal Reserve Board while CPIs of different countries originated from the database of IMF.

\section{Empirical Results and Discussion}

\subsection{Unit Root Tests and Co-Integrations}

Table 1. Panel augmented dickey-fuller unit root test from Jan-1994 to Oct-2014 (number of lags is selected by Schwarz Criterion, max. lag $=15$ )

\begin{tabular}{lllll}
\hline & Developed Countries (p-value) & $\begin{array}{l}\text { Integration } \\
\text { Order }\end{array}$ & Export-Oriented LDCs (p-value) & $\begin{array}{l}\text { Integration } \\
\text { Order }\end{array}$ \\
\hline $\ln X-$ intercept and trend & $0.0343^{* *}$ & $\mathrm{I}(1)$ & $0.0000^{* * *}$ & $\mathrm{I}(0)$ \\
$\mathrm{d}(\ln \mathrm{X})-$ intercept & N/A & & $\mathrm{N} / \mathrm{A}$ & $\mathrm{I}(1)$ \\
$\ln R \mathrm{R}-$ intercept & 0.1869 & $\mathrm{I}(1)$ & $0.0936^{*}$ & \\
$\mathrm{~d}(\ln \mathrm{n}$ ER $)-$ intercept & $0.0000^{* * *}$ & & $0.0000^{* * *}$ & $\mathrm{I}(0)$ \\
$\sqrt{\mathrm{V}}-$ intercept & $0.0013^{* * *}$ & $\mathrm{I}(0)$ & $0.0090^{* * *}$ & \\
$\mathrm{~d}(\sqrt{\mathrm{V}})-$ intercept & N/A & & N/A & $\mathrm{I}(0)$ \\
Mis - intercept & $0.0001^{* * *}$ & $\mathrm{I}(0)$ & $0.0005^{* * *}$ & N/A \\
$\mathrm{d}(\mathrm{Mis})-$ intercept & N/A & & & \\
\hline
\end{tabular}

Table 1 shows the results of Panel ADF unit root tests. The exports series of developed countries was I(1) and that of export-oriented LDCs was I(0). For both developed and export-oriented LDCs, the series of RER were 
non-stationary and I(1). The remaining variables of both developed and export-oriented LDCs were I(0). Table 2 shows the result of individual ADF unit root test. The personal consumption expenditure of U.S. was I(1).

Table 2. Individual augmented dickey-fuller unit root test for U.S. personal consumption expenditure from Jan-1994 to Oct-2014 (number of lags is selected by Schwarz Criterion, max. lag =15)

\begin{tabular}{lll}
\hline & p-value & Integration Order \\
\hline $\ln Y-$ intercept and trend & 0.9202 & $\mathrm{I}(1)$ \\
$\mathrm{d}(\ln Y)-$ intercept & $0.0000^{* * *}$ & \\
\hline Note. $* * *$ and $* * *$ denote significance at the $10 \%, 5 \%$ and $1 \%$ level respectively. &
\end{tabular}

Since not all variables are stationary, it is necessary to test whether those variables are co-integrated. If they are co-integrated, OLS (Ordinary Least Squares) will be used. Otherwise, it is necessary to take the first difference of the variables in the regression. Therefore, the Pedroni Panel Cointegration Test is exercised. The results are shown in Table 3. For developed countries, the null hypothesis that there was not cointegration relationship is rejected at $10 \%$ significant level, thought not at $5 \%$ level. For export-oriented LDCs, the null hypothesis that there was no cointegration relationship is rejected at $1 \%$ significant level. Therefore, the variables for both developed countries and export-oriented LDCs were indeed cointegrated. The results are consistent with the finding of prior empirical studies (Poon et al., 2005; Arize et al., 2000). Level of variables is applied in the OLS regression for estimating the long run relationships.

Table 3. Pedroni panel Co-integration test (number of lags is selected by Schwarz Criterion, max. lag =15)

\begin{tabular}{lll}
\hline Developed Countries & t-statistic & p-value \\
\hline Group rho & -31.72031 & 0.0000 \\
Group ADF & -1.532016 & 0.0628 \\
Export-Oriented LDCs & t-statistic & p-value \\
Group rho & -19.17375 & 0.0000 \\
Group ADF & -8.126949 & 0.0000 \\
\hline
\end{tabular}

\subsection{Regression Results}

The FEM regression results are shown in Table 4 and Table 5. The first noteworthy point is that the Chow Test rejects that there was not structural change between the early period and latter period for both developed countries and export-oriented LDCs at $1 \%$ significant level. Therefore, the following parts will focus on the regression results of each divided period rather than the whole period. Moreover, the chi-square statistics of White-test and Breusch-Godfrey test show that all the regressions have the problems of serial-correlation and heteroscedasticity. Hence, the white robust diagonal coefficient covariance method is used in all equations in order to give consistent standard errors of the coefficients.

Table 4. FEM regression results of developed countries, p-values are in the parentheses (White robust diagonal coefficient covariance method)

\begin{tabular}{llll}
\hline & Jan1994-Dec2007 & Jan2008- Oct2014 & $\begin{array}{l}\text { Jan1994-Oct2014 } \\
\mathbf{N}=\mathbf{2 5 0}\end{array}$ \\
\hline \multirow{2}{*}{ Intercept } & $-9.704395^{* * *}$ & -12.89657 & $-7.695319^{* * *}$ \\
& $(0.0000)$ & $(0.0000)$ & $(0.0000)$ \\
$\ln \mathrm{NER}$ & $0.145623^{* *}$ & $0.409152^{* *}$ & 0.105022 \\
& $(0.0255)$ & $(0.0194)$ & $(0.1219)$ \\
$\ln \mathrm{l}$ & $1.517975^{* * *}$ & $1.897705^{* * *}$ & $1.335639^{* * *}$ \\
& $(0.0000)$ & $(0.0000)$ & $(0.0000)$ \\
$\sqrt{\mathrm{V}}$ & $-0.607307^{* * *}$ & $-3.130437^{* * *}$ & $-1.632659^{* * *}$ \\
& $(0.0005)$ & $(0.0000)$ & $(0.0000)$ \\
\hline
\end{tabular}




\begin{tabular}{|c|c|c|c|}
\hline Mis & $\begin{array}{l}-.0212353 * * \\
(0.0240)\end{array}$ & $\begin{array}{l}-0.360012 \\
(0.1288)\end{array}$ & $\begin{array}{l}-0.805828 * * * \\
(0.0000)\end{array}$ \\
\hline Adjusted R-Square & 0.990955 & 0.984283 & 0.979502 \\
\hline SSR & 12.78106 & 9.397857 & 41.68377 \\
\hline $\begin{array}{l}\text { Chow-test } \mathrm{F} \text {-statistics (for } \mathrm{N} 1=168, \mathrm{~N} 2= \\
82, \text { the critical value of } \mathrm{F} \text {-statistic at } 1 \% \\
\text { significant level is around } 4.33 \text { ) }\end{array}$ & \multicolumn{3}{|c|}{$\mathrm{F}=\frac{(41.68377-(12.78106+9.397857)}{(12.78106+9.397857)} \times \frac{(250-10)}{5}=42.21274$} \\
\hline
\end{tabular}

Note. $* * *$ and $* * *$ denote significance at the $10 \%, 5 \%$ and $1 \%$ level respectively.

The coefficients of RER and U.S. PCE for both developed and export-oriented LDCs in both periods were in correct signs. Therefore, when the purchasing power of USD appreciated or U.S. personal consumption increased, the exports value in currency $i$ from country $i$ will increase, and vice versa. In addition, they were all significant at 5\% level, except that of RER for export-oriented LDCs at the first period, which was only significant at $10 \%$ level.

Table 5. FEM Regression results of export-oriented LDCs, p-values are in the parentheses (White robust diagonal coefficient covariance method)

\begin{tabular}{|c|c|c|c|}
\hline & $\begin{array}{l}\text { Jan1994-Dec2007 } \\
\text { N=168 }\end{array}$ & $\begin{array}{l}\text { Jan2008 - Oct2014 } \\
\mathrm{N}=82\end{array}$ & $\begin{array}{l}\text { Jan1994-Oct2014 } \\
\mathrm{N}=250\end{array}$ \\
\hline Intercept & $\begin{array}{l}-6.338552 * * * \\
(0.0000)\end{array}$ & $\begin{array}{l}-11.68410^{* * *} \\
(0.0001)\end{array}$ & $\begin{array}{l}-5.528734 * * * \\
(0.0000)\end{array}$ \\
\hline lnRER & $\begin{array}{l}0.231818^{*} \\
(0.0551)\end{array}$ & $\begin{array}{l}1.023360^{* * *} \\
(0.0000)\end{array}$ & $\begin{array}{l}0.438477 * * * \\
(0.0000)\end{array}$ \\
\hline $\ln Y$ & $\begin{array}{l}1.073883 * * * \\
(0.0000)\end{array}$ & $\begin{array}{l}1.726981 * * * \\
(0.0000)\end{array}$ & $\begin{array}{l}1.003920^{* * *} \\
(0.0000)\end{array}$ \\
\hline$\sqrt{\mathrm{V}}$ & $\begin{array}{l}0.171595 \\
(0.2855)\end{array}$ & $\begin{array}{l}-0.965058^{* *} \\
(0.0155)\end{array}$ & $\begin{array}{l}0.640466^{* * *} \\
(0.0000)\end{array}$ \\
\hline Mis & $\begin{array}{l}0.265188^{*} \\
(0.0500)\end{array}$ & $\begin{array}{l}0.857315 \\
(0.1374)\end{array}$ & $\begin{array}{l}0.416891 * * * \\
(0.0002)\end{array}$ \\
\hline Adjusted R-Square & 0.973170 & 0.982494 & 0.967658 \\
\hline SSR & 18.05108 & 5.278897 & 31.92350 \\
\hline $\begin{array}{l}\text { Chow-test F-statistics (for } \mathrm{N} 1=168, \mathrm{~N} 2= \\
82, \text { the critical value of F-statistic at } 1 \% \\
\text { significant level is around } 4.33 \text { ) }\end{array}$ & \multicolumn{3}{|c|}{$F=\frac{(31.92350-(18.05108+5.278897)}{(18.05108+5.278897)} \times \frac{(250-10)}{5}=17.68065$} \\
\hline
\end{tabular}

Note. ${ }^{*}, * *$ and $* * *$ denote significance at the $10 \%, 5 \%$ and $1 \%$ level respectively.

The coefficients of RER for export-oriented LDCs were higher than developed countries in both periods. Therefore, exports values of export-oriented LDCs were more sensitive to RER change than those of developed countries. On the other hand, for both periods, the coefficients of real U.S. PCE for export-oriented LDCs were lower than developed countries. For developed countries, results of this paper consist with the conclusion of Cosar (2002), which estimated that the real exchange rate elasticity of exports in Turkey is less than one, whereas the income elasticity is greater than one. Export-oriented LDCs' exports are found to be more sensitive to real exchange rate but less sensitive to U.S. consumption expenditure. These situations are understandable in business sense. In the long run, consumption expenditure in U.S. tends to rise and exporters from LDCs can earn the profits gradually. On the other hand, export-oriented LDCs try to stimulate their exports by depreciating their currencies. Exporters need to be aware of the fluctuation of exchange rates. 
In both periods, the RER volatility had a negative and significant impact on exports from developed countries. The impact of the second period was substantially higher than the first period. When the volatility increased by 1 unit, it would lower exports value from developed countries by only $0.6 \%$ in the first period, but would lower exports value from these countries by $3.1 \%$ in the second period. However, this negative impact on exports from export-oriented LDCs was only significant in the later period (maybe because Financial Crisis made firms considered more on RER volatility), and the magnitude was much lower. According to Arize (1997), the reason for the negative relation for the developed nations is that the firms in developed countries were flexible. When they faced exchange rate volatility, risk-averse exporters would alter the source of demand and supply, modify pricing strategy, or change the distribution of output among countries and sectors in order to lower the risk exposure. Besides, since the U.S. and them are both developed countries, the it is not difficult to attract home demand for commodities which were originally supposed to exported to the U.S.. As a result, when the real exchange rate between their own currency and USD fluctuated greatly, they would reduce their exports to the U.S.

For the export-oriented LDCs, the coefficient of volatility is insignificant in the first period, while it was negative and significant in the second period. Nevertheless, in the second period, the negative impact of volatility on exports from export-oriented LDCs was still lower than those from developed countries. It is because the situations of the export-oriented LDCs were different. First, the firms of the export-oriented LDCs may not be as flexible as those in developed countries, so they could not use distribution strategies to avoid the RER risk. Secondly, their export commodities to U.S., a highly developed country, were less likely suitable to the home consumer. Therefore, if they did not export the commodities to U.S., the commodities could not easily absorb by local customers. Therefore, when they faced volatility RER between their own currency and USD, they would find hard to lower the exports, especially in the first period. In the second period, the distribution system of firms in LDCs improved, and the economic characteristics of their country became similar to developed countries. As a result, when they were facing high RER uncertainty, they can shift their output from U.S. to other nations or home market. However, these abilities of the export-oriented LDCs were still lower than developed countries. Also, exported-oriented LDCs may prefer more to expand the market regardless the potential risk in the early period.

The misalignment variable is only significant for developed countries in the first period. And the effect is negative. Combining with the effect of RER variable, when the purchasing power of U.S. increased, the exports value from developed countries will increase. However, if the purchasing power of U.S. increase too much, i.e. above the long run path calculated by the H-P filter. The positive effect of depreciation in RER will be reduced. One possible explanation is the effect of anti-dumping policy. Generally, anti-dumping does not allow price of export goods lower than the price of goods available for home customers, i.e. "the fair price" (See Crowley, 2007 for details). Also, the RER in this paper can be decompose in $\left(\mathrm{e}_{\frac{\text { currencyi }}{\text { USD }}} \cdot \frac{\mathrm{CPI}_{\text {us }}}{\mathrm{CPI}_{\mathrm{i}}}\right)$, if both the CPIs remain unchanged, when the USD appreciate, it will cause the real price of exports to U.S. become lower relative to goods for home market, and thus trigger the anti-dumping. However, this effect should be also relevant for export-oriented LDCs. Another possible explanation is when export firms from developed countries felt that the U.S. purchasing power was too high, they would adjust or delay the distribution for maximizing the profit. On the other hand, export-oriented LDCs may prefer to increase the value exports, regardless how high was U.S. purchasing power.

\section{Conclusion and Limitation}

This paper discovers that the RER volatility had a significant and negative impact on real exports from developed countries in both periods. However, the RER only had a significant and negative effect on exports from export-oriented LDCs in the later period. This finding shows that exporters in developed became more risk averse to RER risk, or these LDCs started to build up a flexible distribution network and tended to less relying on exports. Since exporters in export-oriented LDCs became risk averse, it is worthy for these countries to improve the system for hedging the currency risk, such as forward market. The weakness is that the expected volatility is unobservable, and $\operatorname{GARCH}(1,1)$ may not fully measure the expected exchange rate volatility. Therefore, later studies need a deeper understanding about the estimation method for the expected volatility. 


\section{References}

Arize, A. C. (1997). Conditional Exchange-Rate Volatility and the Volyme of Foreign Trade: Evidence from Seven Industrialized Countries. Southern Economic Journal, 64(1), 235-254. http://dx.doi.org/10.2307/1061049

Arize, A. C. (1995). The Effects of Exchange-Rate Volatility on U.S. Exports: An Empirical Investigation. Southern Economic Journal, 62(1), 34-43. http://dx.doi.org/10.2307/1061373

Arize, A. C., Osang, T., \& Slottje, D. J. (2000). Exchange-Rate Volatility and Foreign Trade: Evidence from Thirteen LDCs. Journal of Business \& Economic Statistics, 18(1), 10-17. http://dx.doi.org/10.1080/07350015.2000.10524843

Chowdhury, A. R. (1993). Does Exchange Rate Volatility Depress Trade Flows? Evidence from Error-Correction Models. The Review of Economics and Statistics, 75(4), 700-706. http://dx.doi.org/10.2307/2110025

Chowley, M. A. (2007). Cyclical Dumping and US Antidumping Pretection: 1980-2001. Federal Reserve Bank of Chicago Working Paper 2007-21.

Cosar, E. E. (2002). Price and Income Elasticities of Turkish Export Demand: A Panel Data Application. Central Bank Review, 2, 19-53.

Doroodian, K. (1999). Does exchange rate volatility deter international trade in developing countries? Journal of Asian Economics, 10, 465-474. http://dx.doi.org/10.1016/S1049-0078(99)00038-X

Fang, W., Lai, Y., \& Miller, S. M. (2009). Does exchange rate risk affect exports asymmetrically? Asian Evidence. Journal of International Money and Finance, 28, 215-239. http://dx.doi.org/10.1016/j.jimonfin.2008.11.002

Hodrick, R. J., \& Prescoot, E. C. (1997). Postwar U.S. Business Cycles: An Empirical Investigation. Journal of Money, Credit, and Banking, 29(1), 1-16. http://dx.doi.org/10.2307/2953682

Holly, S. (1995). Exchange Rate Uncertainty and Export Performance: Supply and Demand Effects. Scotish Journal of Political Economy, 42(2), 381-391. http://dx.doi.org/10.1111/j.1467-9485.1995.tb01165.x

Koray, F., \& Lastrapes, W. D. (1989). Real Exchange Rate Volatility and U.S. Bilateral Trade: A VAR Approach. The Review of Economics and Statistics, 71(4), 708-712. http://dx.doi.org/10.2307/1928117

Lee, J. (1999). The Effect of Exchange Rate Volatility on Trade in Durables. Review of International Economics, 7(2), 189-201. http://dx.doi.org/10.1111/1467-9396.00156

Li, G. Z., Voon, J. P., \& Ran, J. (2006). Risk, Uncertainty and China's Exports. Australian Economic Paper, 45(2), 158-168. http://dx.doi.org/10.1111/j.1467-8454.2006.00284.x

Nishimura, Y., \& Hirayama, K. (2013). Does Exchange Rate Volatility Deter Japan-China Trade? Evidence from Pre- and Post-Exchange Rate Reform in China. Japan and the World Economy, 90-101. http://dx.doi.org/10.1016/j.japwor.2013.03.002

Oskoose, B., \& Hegerty, S. W. (2009). The Effects of Exchange-Rate Volatility on Commodity Trade between the United States and Mexico. Southern Economic Journal, 75(4), 1019-1044. http://dx.doi.org/10.1111/j.1467-9701.2008.01116.x

Poon, W., Choong, C., \& Habibullah, M. S. (2005). Exchange Rate Volatility and Exports for Selected East Asian Countries Evidence from Error Correction Model. ASEAN Economic Bulletin, 22(2), 144-159. http://dx.doi.org/10.1355/AE22-2B

Pozo, S. (1992). Conditional Exchange Rate Volatility and the Volume of Internation Trade: Evidence From The Early 1900s. Review of Economics and Statistics, 74(2), 325-329. http://dx.doi.org/10.2307/2109665

Sauer, C., \& Bohara, A. K. (2001). Exchange Rate Volatility and Exports: Regional Differences between Developing and Industrialized Countries. Review of International Economics, 9(1), 133-152. http://dx.doi.org/10.1111/1467-9396.00269

Senhadji, A. S., \& Montenegro, C. E. (1999). Time Series Analysis of Export Demand Equations: A Cross-Country Analysis. IMF Staff Papers, 46(3), 259-273. http://dx.doi.org/10.5089/9781451923582.001

Serven, L. (2003). Real Exchange Rate Uncertainty and Private Investment in LDCs. The Review of Economics and Statistics, 85(1), 212-218. http://dx.doi.org/10.1162/rest.2003.85.1.212 


\section{Copyrights}

Copyright for this article is retained by the author(s), with first publication rights granted to the journal.

This is an open-access article distributed under the terms and conditions of the Creative Commons Attribution license (http://creativecommons.org/licenses/by/3.0/). 